\title{
BMJ Open Diagnostic testing and vaccination for COVID-19 among First Nations, Metis and Inuit in Manitoba, Canada: protocol for a nations-based cohort study using linked administrative data
}

Nathan C Nickel, ${ }^{1}$ Wayne Clark, ${ }^{2}$ Wanda Phillips-Beck, ${ }^{3,4}$ Julianne Sanguins, ${ }^{5}$ Jennifer Emily Enns (D) , Josée G Lavoie, ${ }^{1}$ Razvan Romanescu, ${ }^{6}$ Alan Katz, ${ }^{1,7}$ Alyson L Mahar, ${ }^{1}$ Marni Brownell, ${ }^{1}$ Lisa Lix, ${ }^{1}$ Marcelo Urquia, ${ }^{1}$ Miyosha Tso Deh, ${ }^{1}$ Carrie O'Conaill, ${ }^{1}$ Anita Durksen, ${ }^{1}$ Emily Brownell (D) , ${ }^{1}$ The COVID Equity Team

To cite: Nickel NC, Clark W, Phillips-Beck W, et al. Diagnostic testing and vaccination for COVID-19 among First Nations, Metis and Inuit in Manitoba, Canada: protocol for a nations-based cohort study using linked administrative data. BMJ Open 2021;11:e052936. doi:10.1136/ bmjopen-2021-052936

- Prepublication history for this paper is available online. To view these files, please visit the journal online (http://dx.doi org/10.1136/bmjopen-2021052936).

Received 28 April 2021 Accepted 29 June 2021

Check for updates

(C) Author(s) (or their employer(s)) 2021. Re-use permitted under CC BY-NC. No commercial re-use. See rights and permissions. Published by BMJ.

For numbered affiliations see end of article.

Correspondence to Dr Nathan C Nickel;

Nathan.Nickel@umanitoba.ca

\section{ABSTRACT}

Introduction Decades of research demonstrate that First Nations, Metis and Inuit (FN/M/) populations have differential access to diagnostic and therapeutic healthcare. Emerging evidence shows that this continues to be the case during the SARS-CoV-2 pandemic. In an effort to rectify these differences in access to care, our team, which is co-led by FN/M/I partners, will generate and distribute evidence on COVID-19 diagnostic testing and vaccination in high-priority FN/M/l populations in Manitoba, with the goal of identifying system-level and individual-level factors that act as barriers to equitable care and thereby informing Indigenous-led public health responses.

Methods and analysis Our nations-based approach focuses on FN/M/I populations with separate study arms for each group. Linked administrative health data on COVID-19 diagnostic testing and vaccinations are available on a weekly basis. We will conduct surveillance to monitor trends in testing and vaccination among each FN/M/I population and all other Manitobans, map the geographic distribution of these outcomes by health region and tribal council, and identify barriers to testing and vaccination to inform public health strategies. We will follow the course of the pandemic starting from January 2020 and report findings quarterly.

Ethics and dissemination Ethics approvals have been granted by the University of Manitoba Research Ethics Board and from each of our FN/M/I partners' organisations. Our team is committed to engaging in authentic relationship-based research that follows First Nations, Metis and Inuit research ethics principles. Our FN/M/I partners will direct the dissemination of new information to leadership in their communities (health directors, community health organisations) and to decision-makers in the provincial Ministry of Health. We will also publish in open-access journals. The study will create ongoing capacity to monitor Manitoba's pandemic response and ensure potential health inequities are minimised, with learnings applicable to other jurisdictions where detailed administrative data may not be available.

\section{Strengths and limitations of this study}

- The study leverages routinely collected administrative data on the whole population of Manitoba, ensuring accurate representation of all residents in the study findings.

- Our nations-based approach with co-leadership from First Nations, Metis and Inuit partners underlines our commitment to respectful and ethical research engagement with Indigenous peoples.

- Administrative data are by their nature always retrospective and thus are often limited in their use for surveillance; however, we are receiving weekly updates of COVID-19-related administrative data, making our study findings actionable in near real-time.

- Although the repository contains comprehensive data from the Manitoba healthcare system, it lacks information on waiting times and individuals' attitudes towards testing and vaccination, factors that may represent barriers to receiving care.

- Sample size was a concern for this study and we were planning to explore small sample size methods to address this challenge; however, it is now clear that we will likely have a large enough sample to conduct the planned analyses.

\section{INTRODUCTION}

In 2009, the H1N1 influenza pandemic spread rapidly in First Nations, Metis and Inuit $(\mathrm{FN} / \mathrm{M} / \mathrm{I})$ communities, quickly overwhelming health services and human resources. ${ }^{1}$ Despite FN/M/I constituting only $3 \%$ of Canada's population, they represented $12.6 \%$ of confirmed $\mathrm{H} 1 \mathrm{~N} 1$ cases, $17 \%$ of associated hospitalisations and $14 \%$ of ICU admissions. ${ }^{2}$ The failure of the public health system to safeguard $\mathrm{FN} / \mathrm{M} / \mathrm{I}$ from $\mathrm{H} 1 \mathrm{~N} 1$ was a reflection of structural challenges (eg, poverty and 
overcrowding) and burden of disease (eg, higher rates of diabetes, heart disease and lung disease) in FN/M/I communities, ${ }^{34}$ and highlighted the lack of opportunity and agency $\mathrm{FN} / \mathrm{M} / \mathrm{I}$ leaders were granted in protecting their communities. Exclusion from public health planning processes and limited access to vital information on the progression of the pandemic were large contributors to the risks $\mathrm{FN} / \mathrm{M} / \mathrm{I}$ populations faced, ultimately exacerbating existing health inequities between $\mathrm{FN} / \mathrm{M} / \mathrm{I}$ and other Canadians. ${ }^{56}$

In the current SARS-CoV-2 pandemic, there is opportunity to learn from past mistakes. Public health has emphasised the importance of protecting populations at high risk of developing severe disease, including FN/M/I populations, by preventing community transmission of COVID-19, conducting widespread diagnostic testing and prioritising them for vaccination. ${ }^{78}$ However, inequities in access to testing and vaccination persist. In Canada ${ }^{9} 10$ and globally, ${ }^{11-13}$ COVID-19 testing has not consistently adhered to best-practice guidelines, and although First Nations have been recognised as a priority population for vaccination in many Canadian jurisdictions and included in plans for vaccine roll-outs, Metis and Inuit leadership have largely been sidelined. ${ }^{14-16}$ In Manitoba, where FN/M/I collectively make up $18 \%$ of the population, the Canadian public health response has not been sufficient to control COVID-19 outbreaks in FN/M/I communities. ${ }^{17}$ Many communities have already been hit hard by COVID19, with deaths in First Nations accounting for $17 \%$ of the province's total deaths, $33 \%$ of hospitalisations and $55 \%$ of intensive care admissions, ${ }^{18}$ and outbreaks continue to threaten even while vaccination efforts are underway. ${ }^{19}$

$\mathrm{FN} / \mathrm{M} / \mathrm{I}$ community leaders need to be recognised as key decision-makers in the protection of their communities, and they require up-to-date information on COVID-19 testing and vaccination to inform the assessment of ongoing risks and strategies to best mitigate risks and identify barriers their community members are experiencing with respect to access to care. Currently, the provincial health ministry provides Manitoba First Nations with the total number of First Nations people who have accessed testing and vaccination services, but even these basic statistics are not available to Metis or Inuit populations. Other outputs that would be useful for planning include population-based testing and vaccination rates, changes in rates over time and information on how non-health population factors like income, geography and mental health modify rates of healthcare use.

In recognition of this need for current, detailed and comprehensive information, we have secured funding from the Canadian Institutes of Health Research and Research Manitoba to monitor COVID-19 testing and vaccination rates among $\mathrm{FN} / \mathrm{M} / \mathrm{I}$ populations in Manitoba. Within the context of this study, knowledge gaps and new questions posed by FN/M/I leadership can be rapidly addressed. Led by a team of researchers from the University of Manitoba, the First Nations Health and Social Secretariat of Manitoba (FNHSSM), the Manitoba
Metis Federation (MMF) and the Manitoba Inuit Association (MIA), the proposed research study will provide an evidence base for Indigenous-led public health responses and work to minimise COVID-19 health inequities over the course of the pandemic.

\section{METHODS AND ANALYSIS}

\section{Applying a nations-based approach to FN/M/I research}

In this study, the research team will adopt a nations-based approach ('nations-based approach' is the preferred term among our Indigenous partners in Manitoba because it is more descriptive than the more commonly used 'distinctions-based approach'), which acknowledges the distinct histories, interests and priorities of $\mathrm{FN} / \mathrm{M} / \mathrm{I}^{1}$ Indigenous organisations have been advocating for nations-based research approaches for many years. ${ }^{2-4}$ Despite long delays in gaining this recognition, the United Nations Declaration on the Rights of Indigenous Peoples now affirms FN/M/I as 'equal to all other peoples, while recognising the right of all peoples to be different, to consider themselves different, and to be respected as such ${ }^{20}$ This study contributes to the important work of decolonising health research, the first step of which is to engage $\mathrm{FN} / \mathrm{M} / \mathrm{I}$ people in the research process, and the second, to employ a nations-based research approach. ${ }^{5-7}$

\section{Patient and public involvement}

As this study uses routinely collected administrative data to examine outcomes, we do not expect to have any direct patient involvement. However, we have sought the input and expertise of $\mathrm{FN} / \mathrm{M} / \mathrm{I}$ stakeholders and knowledge users from the start of the research onwards to ensure the findings are relevant for these groups. Our FN/M/I partners include representatives from the FNHSSM, the MMF and the MIA. Our goal in engaging this group of stakeholders from the research proposal stage onwards is to ensure that their knowledge, perspectives and experiences are represented in the work and that our findings address the most critical issues in a culturally sensitive way. They will be instrumental in knowledge translation activities, as described in more detail in a later section. Also, the study has support from the provincial Department of Health, who will be briefed on study findings as directed by our FN/M/I partners.

\section{Study setting and design}

This study will use whole-population administrative data from Manitoba to examine COVID-19 diagnostic testing and vaccination rates, starting with the first case of COVID-19 identified in Canada (22 January 2020) until the end of the funding period in 2022. Manitoba (population 1.4 million) has the highest proportion of Indigenous residents among Canadian provinces. ${ }^{21}$ Indigenous people and policy-makers have argued that no single entity represents or serves all Indigenous peoples, and that specific First Nations, Metis and Inuit responses are required for different policy areas. ${ }^{22}$ This is reflected 
Table 1 Cohort development

\begin{tabular}{|c|c|c|}
\hline $\begin{array}{l}\text { Study arm 1: } \\
\text { First Nations cohort }\end{array}$ & $\begin{array}{l}\text { Study arm 2: } \\
\text { Metis cohort }\end{array}$ & $\begin{array}{l}\text { Study arm 3: } \\
\text { Inuit cohort }\end{array}$ \\
\hline $\begin{array}{l}\text { The cohort will include all registered First Nations people } \\
\text { living in Manitoba at any point from } 1 \text { January } 2020 \text { to the } \\
\text { end of the study. }\end{array}$ & $\begin{array}{l}\text { The cohort will include all Metis living in } \\
\text { Manitoba at any point from } 1 \text { January } \\
2020 \text { to the end of the study. }\end{array}$ & $\begin{array}{l}\text { The cohort will include all Inuit living in } \\
\text { Manitoba at any point from } 1 \text { January } \\
2020 \text { to the end of the study. }\end{array}$ \\
\hline $\begin{array}{l}\text { Registered First Nations people will be identified } \\
\text { using the Manitoba First Nations Research File, } \\
\text { cross-referenced with four other datasets that include } \\
\text { information on First Nations identity (see table } 2 \text { for } \\
\text { details). All individuals who are identified as First Nations } \\
\text { (or who have self-identified as First Nations) in at least } \\
\text { one of these five datasets will be included in the cohort. } \\
\text { Additionally, we will include all mothers of First Nations } \\
\text { people in the cohort using existing mother-child linkages } \\
\text { in the repository. }\end{array}$ & $\begin{array}{l}\text { Metis citizens will be identified using the } \\
\text { Manitoba Metis Registry. }\end{array}$ & $\begin{array}{l}\text { Inuit will be identified using data collected } \\
\text { by the Manitoba Inuit Association for an } \\
\text { ongoing administrative data study. These } \\
\text { data are already housed at the Manitoba } \\
\text { Centre for Health Policy. }\end{array}$ \\
\hline $\begin{array}{l}\text { The comparison group will comprise all other } \\
\text { Manitobans, including Metis and Inuit. }\end{array}$ & $\begin{array}{l}\text { The comparison group will comprise } \\
\text { all other Manitobans, including First } \\
\text { Nations and Inuit. }\end{array}$ & $\begin{array}{l}\text { The comparison group will comprise all } \\
\text { other Manitobans, including First Nations } \\
\text { and Metis. }\end{array}$ \\
\hline
\end{tabular}

in the design of our study, which will be conducted in three separate arms, one for each of the three Indigenous groups. No comparisons will be made between FN/M/I cohorts (eg, First Nations vs Metis vs Inuit); instead, each will be compared individually with all other Manitobans. This study design has been adopted out of respect to our $\mathrm{FN} / \mathrm{M} / \mathrm{I}$ research partners, who are adamant that analyses be specific to each distinct group rather than grouping Indigenous peoples together, and that comparisons be made only between their people and all others in the larger population, in accordance with the guiding principles of Indigenous data sovereignty. The rationale for this design is that it prevents comparisons between Indigenous groups, which would not produce any actionable evidence. See table 1 for the cohort development plan.

\section{Data sources}

The study will use linked administrative data from the Manitoba Population Research Data Repository at the Manitoba Centre for Health Policy (MCHP). The repository is a secure information-rich environment containing de-identified individual-level records on nearly the entire population of Manitoba (The Manitoba Population Research Data Repository contains administrative records on $>99.9 \%$ of the Manitoba population. Health records in a few select datasets may be incomplete because they are under federal jurisdiction (eg, for military personnel, individuals incarcerated in federal prisons and individuals living in First Nations communities.)) and includes registries of $\mathrm{FN} / \mathrm{M} / \mathrm{I}$ people living in Manitoba. Before the records arrive at MCHP, names and addresses are removed and a scrambled 9-digit personal health identification number is attached to each record by a trusted third party through deterministic data linkage. This allows us to link together individuals' records across datasets and over time.

The datasets and variables of interest for this study are listed in table 2. Most of these datasets have been used extensively in previous research at MCHP and their validity for population health studies has been well documented. ${ }^{23-26}$ The new COVID-19 datasets have undergone a data quality evaluation since being brought into the repository (testing dataset fields are 86\%-99\% complete;

Table 2 MCHP repository databases used in this study

\begin{tabular}{|c|c|}
\hline Database & Data fields of interest \\
\hline $\begin{array}{l}\text { Manitoba Health Insurance } \\
\text { Registry }\end{array}$ & Date of birth, sex \\
\hline $\begin{array}{l}\text { Diagnostic Services Manitoba } \\
\text { (Laboratory Tests) }\end{array}$ & $\begin{array}{l}\text { COVID-19 diagnostic test } \\
\text { results and indication for test }\end{array}$ \\
\hline $\begin{array}{l}\text { Public Health Information } \\
\text { Management System (Vaccination) }\end{array}$ & $\begin{array}{l}\text { COVID-19 vaccination records } \\
\text { (vaccine type, number of doses) }\end{array}$ \\
\hline Medical claims & $\begin{array}{l}\text { Reason for physician visit (ICD } \\
\text { codes) }\end{array}$ \\
\hline $\begin{array}{l}\text { Hospital Discharge Abstract } \\
\text { Database }\end{array}$ & $\begin{array}{l}\text { Reason for hospitalisation (ICD } \\
\text { codes) }\end{array}$ \\
\hline ICU admissions & $\begin{array}{l}\text { Reason for admission to ICU } \\
\text { (ICD codes) }\end{array}$ \\
\hline Vital statistics & $\begin{array}{l}\text { Date of death and reason for } \\
\text { death }\end{array}$ \\
\hline $\begin{array}{l}\text { Drug Programme Information } \\
\text { Network }\end{array}$ & Prescription drugs \\
\hline $\begin{array}{l}\text { Manitoba First Nations Research } \\
\text { File }\end{array}$ & First Nations identity \\
\hline Metis Population Database & Metis identity \\
\hline Manitoba Inuit Registry & Inuit identity \\
\hline Universal Newborn Screen Data & First Nations identity \\
\hline Healthy Baby Programme Data & First Nations identity \\
\hline $\begin{array}{l}\text { Employment and Income } \\
\text { Assistance Data }\end{array}$ & First Nations identity \\
\hline $\begin{array}{l}\text { Early Development Instrument } \\
\text { Data }\end{array}$ & First Nations identity \\
\hline Canada Census & $\begin{array}{l}\text { Postal codes (urban/rural } \\
\text { geography) }\end{array}$ \\
\hline
\end{tabular}

ICD, International Classification of Diseases; ICU, intensive care unit; MCHP, Manitoba Centre for Health Policy. 
vaccination dataset fields are $100 \%$ complete with no missing values).

One of the notable challenges of working with administrative data is the time delay between a healthcare contact and the acquisition of that record into the repository. Most datasets in the repository are updated no more than once a year. However, MCHP has secured agreements from its data providers for weekly updates of COVID-19 testing and vaccination data so that results can be continuously monitored.

\section{Analysis plan}

We will first summarise distributions of baseline characteristics of the three cohorts, including small area-level income, sex, age and region of residence (ie, the five provincial health authorities). First Nations and Metis also have defined geographical boundaries in Manitoba that are important for their own planning of health and social-thus, where sample size allows, we will also describe the distribution of cohort characteristics by Tribal Council (for First Nations) and Metis Region (for Metis). Equivalent community groupings do not exist for Inuit in Manitoba.

\section{COVID-19 diagnostic testing and vaccination rates}

Rate ratios will be calculated using generalised linear models with generalised estimating equations (GEEs), with a $\log$ population offset for each group and specific clustering (such as area by time) specified in the model. The total population size for each group will be determined from the Manitoba Health Insurance Registry, the First Nations Research File, the Metis Registry and the MIA data. We will model COVID-19 testing and vaccination rates using a monthly rolling average, with an $\mathrm{FN} / \mathrm{M} / \mathrm{I}$ indicator as the explanatory variable of interest to determine if there are differences between each group and all other Manitobans. We will include a time variable and a (time $\times \mathrm{FN} / \mathrm{M} / \mathrm{I}$ group) interaction in the models to examine changes in testing and vaccination rates over time and differences between FN/M/I and all other Manitobans. We will also account for other factors (eg, region of residence, geography, test positivity rates in the region, area-level income and 5-year prevalence of physical and mental health comorbidities) that may predict testing or vaccination. We will include a measure of remoteness, that is, the distance between geographical centre of an individual's residential postal code and the nearest testing site/vaccination site, to test whether remoteness acts as a barrier to vaccination. Where sample size allows, we will also look for differences among Tribal Councils (for First Nations) and Regions (for Metis). Model fit for GEEs will be assessed using overall goodness-of-fit statistics and residual analyses.

\section{Geographical distribution of COVID-19 testing and vaccination}

Using postal codes, we will generate dot plots to show where people who are tested and vaccinated live. Random variation will be added to the plot coordinates to protect individual Manitobans' identities. We will also generate area plots depicting testing rates for each Regional Health Authority in Manitoba, each Neighbourhood Cluster in Winnipeg, each Tribal Council Area (for First Nations) and each Metis Region. Testing rates will be calculated as the number of tests per square $\mathrm{km}$ and we will determine whether testing rates differ by region and across time. As the number of COVID-19 cases increases in Manitoba, we will also begin to generate maps of where cases are identified.

\section{Ongoing monitoring of COVID-19 testing and vaccination}

The statistical code used to generate the FN/M/I cohorts and the statistical models will be routinely applied to the administrative data in the repository to auto-monitor and generate regular quarterly reports on testing and vaccination rates in each cohort. This will allow us to monitor in an ongoing way whether differences in COVID-19 healthcare are occurring between FN/M/I and all other Manitobans. All statistical analyses will be conducted in SAS V.9.4. Reports will be generated in Tableau, which offers a user-friendly interactive dashboard feature that we expect will be helpful to decision-makers as they explore the data.

\section{ETHICS AND DISSEMINATION \\ Ethical considerations}

Ethics approvals have been granted by the University of Manitoba Health Research Ethics Board (HS24133H2020:345), the First Nations Health Information Research Governance Committee at FNHSSM, the Ethics Committee at MMF and the Executive at MIA. The government of Manitoba's Health Information Privacy Committee has also reviewed the protocol and provided approval.

Our team is committed to engaging in authentic relationship-based research that follows the First Nations principles of Ownership, Control, Access and Possession, ${ }^{27}$ the Metis principles of Ownership, Control, Access and Stewardship ${ }^{28}$ and Inuit Qaujimajatuqangit principles $^{29}$ in each respective study arm. We will also follow the guidelines outlined in the Tri-Council Policy Statement: Ethical Conduct for Research Involving Humans (TCPS 2-Chapter 9), ${ }^{30}$ and apply the University of Manitoba Framework for Research Engagement with First Nations, Metis, and Inuit peoples. ${ }^{31}$ The funding proposal was built on existing relationships between scholars at the University of Manitoba, FNHSSM, MMF and MIA; FN/M/I researchers are principal investigators in each respective study arm. The study objectives reflect each partner's distinct priorities, and the research approach has been designed to incorporate First Nations, Metis and Inuit perspectives.

\section{Dissemination plans}

Our FN/M/I co-leads will guide our knowledge dissemination and exchange strategy. Initially, we have 
planned to conduct all communications by videoconference or teleconference, with hopes that later meetings may be able to occur in person. We have set up a research team meeting schedule for each study arm. The FN/M/I leads and other representatives from their organisations will attend team meetings to review the study results as they become available and provide contextual information critical to interpreting them. The research team will follow their lead in delivering the findings to their target audiences. We will meet with wider leadership from FNHSSM, MMF and MIA (in separate gatherings for each group) four times during the course of the research: once early in the project to share preliminary findings and set up plans for data visualisation and dashboard creation, and then at regular quarterly intervals to share and discuss updated results. Elders and knowledge keepers from each group will be invited to join these discussions. A facilitator at MCHP will work with the FN/M/I leads and the MCHP analysts, research staff and trainees to create printed and online dissemination materials (reports, tables and graphs, summaries, infographics) appropriate for distribution to the $\mathrm{FN} / \mathrm{M} / \mathrm{I}$ organisations and their community members. Where appropriate, $\mathrm{FN} / \mathrm{M} / \mathrm{I}$ partners will lead the dissemination of the study's findings to their community health organisations, health directors and the provincial Department of Health. This latter communication will be facilitated through MCHP, which has long-standing relationships with decision makers in Manitoba Health. Lastly, the team will co-write manuscripts to be published in peer-reviewed open-access journals and present the findings at scientific conferences.

\section{Author affiliations}

${ }^{1}$ Department of Community Health Sciences, University of Manitoba Faculty of Health Sciences, Winnipeg, Manitoba, Canada

${ }^{2}$ Manitoba Inuit Association, Winnipeg, Manitoba, Canada

${ }^{3}$ First Nations Health and Social Secretariat of Manitoba, Winnipeg, Manitoba,

Canada

${ }^{4}$ College of Nursing, University of Manitoba, Winnipeg, Manitoba, Canada

${ }^{5}$ Manitoba Metis Federation, Winnipeg, Manitoba, Canada

${ }^{6}$ Biostatistics, University of Manitoba Faculty of Health Sciences, Winnipeg,

Manitoba, Canada

${ }^{7}$ Department of Family Medicine, University of Manitoba Faculty of Health Sciences, Winnipeg, Manitoba, Canada

Acknowledgements The authors wish to acknowledge the Manitoba Centre for Health Policy for use of data contained in the Population Health Research Data Repository under project \#2020-066 (HIPC \#2020/2021-25). The COVID Equity Team includes: Marni Brownell; Mariette Chartier; A. Frances Chartrand; Dan Chateau; Wayne Clark; Michelle Driedger; Rachel Dutton; Jeanette Edwards; Jennifer E. Enns; Alan Katz; Josée Lavoie; Lisa Lix; Alyson Mahar; Nathan C. Nickel; Wanda Phillips-Beck; Razvan Romanescu; Julianne Sanguins; Leona Star and Marcelo Urquia.

Contributors The study was conceived by NCN, WP-B, JS and WC, with input from co-investigators JGL, JEE, AK, ALM, MB, LL, MU and RR. All other members of the COVID Equity Team, including MC, AFC, DC, MTD, RD, JE and LS, contributed to writing the successful grant proposal. NCN and JEE drafted the paper with input from $C O^{\prime} C, A D, M T D$ and $E B$, and all other authors critically reviewed it before submission.
Funding This research study is supported by a COVID-19 Rapid Research Operating Grant from the Canadian Institutes of Health Research (VR5-172697) and a 2020 Manitoba COVID-19 Rapid Response Research Grant from Research Manitoba (RM-4447).

Competing interests None declared.

Patient and public involvement Patients and/or the public were involved in the design, or conduct, or reporting, or dissemination plans of this research. Refer to the 'Methods' section for further details.

Patient consent for publication Not required.

Provenance and peer review Not commissioned; peer reviewed for ethical and funding approval prior to submission.

Open access This is an open access article distributed in accordance with the Creative Commons Attribution Non Commercial (CC BY-NC 4.0) license, which permits others to distribute, remix, adapt, build upon this work non-commercially, and license their derivative works on different terms, provided the original work is properly cited, appropriate credit is given, any changes made indicated, and the use is non-commercial. See: http://creativecommons.org/licenses/by-nc/4.0/.

ORCID iDs

Jennifer Emily Enns http://orcid.org/0000-0001-7805-7582

Emily Brownell http://orcid.org/0000-0001-8151-8394

\section{REFERENCES}

1 The National Collaborating Centre for Aboriginal Health. The 2009 H1N1 influenza pandemic among first nations, Inuit and Metis peoples in Canada: epidemiology and gaps in knowledge, 2016. Available: http://www.nccah-ccnsa.ca/Publications/Lists/ Publications/Attachments/174/NCCAH-FSInfluenzaEpidemiology-\% OAPart01-Halseth-EN-Web.pdf

2 Spence N, White JP. Scientific Certainty in a Time of Uncertainty: Predicting Vulnerability of Canada's First Nations to Pandemic H1N1/09. Int Indig Policy J 2010;1.

3 Katz A, Avery Kinew K, Star L. The health status of and access to healthcare by registered first nation peoples in Manitoba 2019.

4 et alMartens P, Bartlett J, Burland E. Profile of Metis health status and healthcare utilization in Manitoba: a population-based study, 2010. Available: http://www.mmf.mb.ca/docs/metis_health_status_ report.pdf

5 The National Collaborating Centre for Aboriginal Health. Pandemic Planning in Indigenous Communities: Lessons Learned from the 2009 H1N1 Influenza Pandemic in Canada, 2016. Available: https:// www.ccnsa-nccah.ca/docs/other/FS-InfluenzaPandemic-EN.pdf

6 Richardson KL, Driedger MS, Pizzi NJ, et al. Indigenous populations health protection: a Canadian perspective. BMC Public Health 2012;12:1098.

7 Bedford J, Enria D, Giesecke J. COVID-19: towards controlling of a pandemic. Lancet.

8 Driedger M, Maier R, Jardine C. 'Damned if you do, and damned if you don't': communicating about uncertainty and evolving science during the H1N1 influenza pandemic. J Risk Res 2018.

9 Laupacis A. Feeling pessimistic about COVID-revealed inequities. CMAJ Blogs.

10 Bellegarde P. Opinion: the COVID-19 crisis on first nations: a reminder of our inequality and an opportunity for change. Available: theglobeandmail.com

11 Kirby T. Evidence mounts on the disproportionate effect of COVID-19 on ethnic minorities. Lancet Respir Med 2020;8:1-2.

12 BBC. Coronavirus: Black Britons face "twice the risk" of death, says ONS.

13 Thebault R, Ba Tran A, Williams V. African Americans are at higher risk of death from coronavirus. Available: washingtonpost.com

14 MacLean C. Métis, Inuit in Manitoba want similar COVID-19 vaccine priority as first nations, 2021. CBC News. Available: https://www.cbc. $\mathrm{ca} /$ news/canada/manitoba/indigenous-manitobans-vaccine-priority1.5926939

15 Stranger D. Manitoba Métis call for public inquiry for not being prioritized in COVID-19 vaccine campaign, 2021. APTN News. Available: https://www.aptnnews.ca/national-news/manitoba-metiscall-for-public-inquiry-for-not-being-prioritized-in-covid-19-vaccinecampaign/

16 Mcalister FA, Bushnik T, Leung AA. Informing COVID-19 vaccination priorities based on the prevalence of risk factors among adults in Canada. CMAJ. 
17 Kirkup K, McLeod M. Several first nations grapple with confirmed COVID-19 cases, press government for help. Available: https://www. theglobeandmail.com/

18 Macyshon J, Jones A, CTV News. Variants may have spread to two remote first nations in Manitoba. Available: https://www.ctvnews.ca/ canada/variants-may-have-spread-to-two-remote-first-nations-inmanitoba-1.5310383

19 Kirkup K. Manitoba first nations grapple with COVID-19 outbreaks, 2020. The globe and mail. Available: https://www.theglobeandmail. com/canada/article-manitoba-first-nations-grapple-with-covid-19outbreaks/

20 United Nations. United nations Declaration on the rights of Indigenous peoples, 2007. Available: https://www.un.org/ development/desa/indigenouspeoples/wp-content/uploads/sites/19/ 2018/11/UNDRIP E web.pdf

21 Statistics Canada. 2016 Census - Aboriginal Peoples - Province of Manitoba. Focus on Geography Series. Published 2019. Available: https://www12.statcan.gc.ca/census-recensement/2016/as-sa/ fogs-spg/Facts-PR-Eng.cfm?TOPIC=9\&LANG=Eng\&GK=PR\&GC=46 [Accessed October 13, 2020].

22 Government of Canada. Crown-Indigenous Relations and Northern Affairs Canada. Published, 2020. Available: https://www.canada. $\mathrm{ca} / \mathrm{en} / \mathrm{crown}$-indigenous-relations-northern-affairs.html [Accessed September 28, 2020].

23 Roos LL, Menec V, Currie RJ. Policy analysis in an information-rich environment. Soc Sci Med 2004;58:2231-41.
24 Roos LL, Brownell M, Lix L, et al. From health research to social research: privacy, methods, approaches. Soc Sci Med 2008;66:117-29.

25 Roos LL, Gupta S, Soodeen R-A, et al. Data quality in an informationrich environment: Canada as an example. Can J Aging 2005;24 Suppl 1:153-70.

26 Jutte DP, Roos LL, Brownell MD. Administrative record linkage as a tool for public health research. Annu Rev Public Health 2011;32:91-108.

27 National Aboriginal Health Organization. OCAP: ownership, control, access and possession: sanctioned by the first nations information governance Committee; 2007.

28 Schroth RJ, Cheba V. Determining the prevalence and risk factors for early childhood caries in a community dental health clinic. Pediatr Dent 2007;29:387-96.

29 Karetak J, Tester F, Tagalik S. Inuit Qaujimajatuqangit: what Inuit have always known to be true. Fernwood Publishing, 2017.

30 Government of Canada. Tri-Council policy statement (2018) chapter 9: research involving the first nations, Inuit and Métis peoples of Canada, 2019. Available: https://ethics.gc.ca/eng/tcps2-eptc2 2018_chapter9-chapitre9.html [Accessed 4 Sep 2020].

31 First Nations Metis and Inuit Health Research Strategic Planning Committee. Framework for research engagement with first nations, Metis, and Inuit peoples, 2013. Available: https://umanitoba.ca/ faculties/health_sciences/medicine/media/UofM_Framework Report_web.pdf 